\title{
Extensive investigation of patients with mild elevations of serum amylase and/or lipase is 'low yield'
}

\author{
Michael F Byrne MA MD MRCP ${ }^{1}$, Robert M Mitchell MB BCh MRCP ${ }^{1}$, Helen Stiffler RSN ${ }^{1}$, \\ Paul S Jowell MB ChB ${ }^{1}$, Malcolm S Branch $\mathrm{MD}^{1}$, Theodore N Pappas $\mathrm{MD}^{2}$, \\ Doug Tyler MD ${ }^{2}$, John Baillie MB ChB FRCP ${ }^{1}$
}

MF Byrne, RM Mitchell, H Stiffler, PS Jowell, MS Branch, TN Pappas, D Tyler, J Baillie. Extensive investigation of patients with mild elevations of serun amylase and/or lipase is 'low yield'. Can J Gastroenterol 2002;16(12):849-854.

BACKGROUND: Serum amylase and lipase levels are widely used as markers of pancreatic inflammation. However, it would seem that mild elevations of amylase and lipase rarely predict significant pancreatic pathology. Pancreatic imaging tests are expensive. The gold standard, endoscopic retrograde cholangiopancreatography, carries risk of morbidity and mortality. OBJECTIVE: To determine whether extensive investigation of patients with mild, nonspecific abdominal symptoms and mild elevations of amylase and/or lipase results in a significant diagnostic yield.

METHODS: Outpatient evaluations were retrospectively analyzed over 12 months. Inclusion criteria were nonspecific abdominal pain, and mild elevations (less than three times the upper limit of normal) of serum amylase or lipase, or both. Exclusion criteria included a history of chronic pancreatitis, elevation of liver tests and acute pain syndromes.

RESULTS: Nineteen patients over the study period met the criteria. Of the nineteen patients, $58 \%$ had elevation of lipase alone, $21 \%$ amylase alone and $21 \%$ had elevations of both. In addition, $89.5 \%$ of the patients had nonspecific abdominal pain. After imaging with one or more of ultrasound, computed tomography, magnetic resonance cholangiopancreatography, endoscopic ultrasound and endoscopic retrograde cholangiopancreatography, small bowel follow through or hepatobiliary scanning, $78.9 \%$ patients were thought to have a normal pancreas. Of the remaining patients, $15.8 \%$ had mild or equivocal changes of chronic pancreatitis, and one patient was found to have a pancreatic tail pseudocyst. The average cost of investigation was US $\$ 2,255$, taking only direct procedural costs into account. No patient was found to have malignancy.

CONCLUSIONS: The majority of patients with nonspecific abdominal pain and isolated elevations of amylase and/or lipase (less than three times the upper limit of normal) had no identifiable pancreatic pathology. The diagnostic yield in patients with mild elevations of lipase alone was particularly poor. The cost effectiveness and risk-benefit ratio of extensive investigation of this group of patients warrants further study.

Key Words: Amylase; Lipase; Low yield; Mild elevations; Pancreas

\section{Des examens élaborés chez des patients} présentant une légère augmentation de l'amylase ou de la lipase sérique sont peu utiles

HISTORIQUE : Les taux d'amylase et de lipase sériques sont largement utilisés comme marqueurs de l'inflammation du pancréas. Cependant, il semble que de faibles élévations de l'amylase et de la lipase laissent rarement présager une pathologie pancréatique importante. La cholangiopancréatographie rétrograde endoscopique, qui représente le traitement standardisé, comporte des risques de morbidité et de mortalité. OBJECTIF : Déterminer si des examens élaborés chez des patients souffrant de symptômes abdominaux légers et non spécifiques et de légères augmentations de l'amylase ou de la lipase laissent présager une issue diagnostique d'importance.

suite à la page suivante

${ }^{1}$ Division of Gastroenterology, Department of Medicine and ${ }^{2}$ Department of Surgery, Duke University Medical Center, Durham, North Carolina, USA

Correspondence: Dr Michael F Byrne, Box 3189, Duke University Medical Center, Durham, North Carolina 27710, USA.

Telephone 919-684-3894, fax 919-684-4695, e-mail byrne006@mc.duke.edu

Received for publication June 10, 2002. Accepted November 4, 2002 
MÉTHODOLOGIE : Les évaluations des patients en clinique externe ont fait l'objet d'une analyse rétrospective pendant une période de 12 mois. Les critères d'inclusion étaient une douleur abdominale non spécifique et de légères augmentations (moins de trois fois la limite supérieure de la normale) de l'amylase ou de la lipase sériques, ou de ces deux enzymes. Les critères d'exclusion incluaient des antécédents de pancréatite chronique, une augmentation des résultats aux examens hépatiques et des syndromes de douleur aiguë.

RÉSULTATS : Dix-neuf patients correspondaient aux critères pendant la période de l'étude. De ce nombre, $58 \%$ présentaient une élévation de la lipase seule, $21 \%$, de l'amylase seule, et $21 \%$, de ces deux enzymes. De plus, $89,5 \%$ des patients souffraient de douleurs abdominales non spécifiques. Après avoir subi une imagerie au moyen d'une échographie, d'une tomographie densitométrique, d'une cholangiopancréatographie par résonance magnétique, d'une endoscopie, d'une cholangiopancréatographie endoscopique rétrograde, d'un transit du grêle, d'un dépistage hépatobiliaire ou de plusieurs de ces interventions, 78,9\% patients étaient présumés avoir un pancréas normal. Parmi les autres patients, 15,8\% présentaient des modifications bénignes ou équivoques de pancréatite chronique, et l'un d'eux souffrait d'un pseudokyste de la queue du pancréas. Le coût moyen des examens s'élevait à 2255 \$US, en ne tenant compte que des coûts directs des interventions. Aucun patient ne présentait de malignité.

CONCLUSIONS : La majorité des patients souffrant de douleurs abdominales non spécifiques et d'élévations isolées de l'amylase ou de la lipase (moins de trois fois la limite supérieure de la normale) ne présentaient pas de pathologie pancréatique repérable. Les résultats diagnostiques des patients présentant une élévation de la lipase seulement étaient particulièrement peu significatifs. La rentabilité et l'analyse coût-bénéfice de l'examen détaillé de ce groupe de patients mérite des études plus approfondes.
Serum amylase and lipase levels are widely used as markSers of pancreatic inflammation and irritation (1). A diagnosis of acute pancreatitis is based on a combination of clinical presentation, laboratory and radiological findings. Results of serum amylase levels are usually available quickly, but this serological test has a specificity of less than $70 \%$ when the upper limit of the normal (ULN) range is used as the cutoff value (2). Serum lipase estimation gives greater specificity than amylase, and the simultaneous determination of both of these parameters increases the sensitivity and specificity for detecting acute pancreatitis to around $90 \%$ to $95 \%(3,4)$. Most experts agree that the estimation of amylase or lipase levels is not useful in the diagnosis of chronic pancreatitis, because serum levels of these enzymes are frequently normal in this setting.

In patients who are asymptomatic or who have nonspecific abdominal pain, it has been our subjective impression that mild elevations of amylase and lipase may not predict significant pancreatic pathology. Chronic, nonpathological hyperamylasemia of pancreatic origin has not been studied in detail but has recently been described in small series (5-8). The significance of an isolated elevation of pancreatic lipase is even more obscure (9). Imaging tests to evaluate the pancreas, such as computed tomography (CT), transabdominal ultrasound, magnetic resonance imaging, endoscopic retrograde cholangiopancreatography (ERCP) and endoscopic ultrasound (EUS) are expensive. In addition, ERCP, the 'gold standard' for assessing pancreatic duct anatomy, carries an appreciable risk of morbidity and mortality. We sought to determine whether extensive investigation of patients with mild nonspecific abdominal symptoms and mild elevations of amylase and/or lipase results in a significant diagnostic yield.

\section{PATIENTS AND METHODS}

A retrospective analysis of outpatient evaluations at the Hepatobiliary and Pancreatic Disorders Clinic at Duke University Medical Center (DUMC) over a consecutive 12-month period from October 2000 to September 2001 was conducted by a chart review. Patients were referred to these clinics from primary care physicians, internists, surgeons and other hospital-based doctors. For the purposes of this retrospective study, inclusion criteria were nonspecific abdominal pain and mild elevations (less than three times the ULN) of serum amylase, serum lipase or both. In most cases, the patient's amylase, lipase or both had been persistently elevated over a period ranging from several weeks to months; a few patients had had isolated enzyme elevations. Exclusion criteria included a history of chronic pancreatitis or any complication thereof, a history of excessive use of alcohol over time, any elevation of liver function tests, acute pain syndromes, renal insufficiency, intestinal obstruction and elevations of amylase and/or lipase greater than three times the ULN. The authors used a cutoff limit for amylase and lipase of three times the ULN as this level is used in many studies of pancreatitis, particularly in those attempting to predict severity of disease based on amylase and lipase levels (10-12). All patients identified in this retrospective study who met these criteria had been investigated for the cause of their nonspecific symptoms and elevated levels of amylase, lipase or both enzymes by a combination of clinical, laboratory, radiological or endoscopic investigations as deemed necessary in each case. Radiological investigations included abdominal CT, ultrasound and magnetic resonance imaging (including magnetic resonance cholangiopancreatography [MRCP]), small bowel follow through studies, hepatobiliary radionuclide imaging and oral cholecystography. All radiological studies were reported by faculty in the abdominal radiology section at DUMC. Endoscopic investigations included standard esophagogastroduodenoscopy, ERCP and EUS, and were performed by, or in the presence of, gastroenterology faculty at DUMC.

To estimate the cost of investigation of these patients with nonspecific symptoms and mild elevations of amylase and/or lipase, a simple calculation based on the 2000 DUMC charges for the particular endoscopic or radiological tests was used. These cost estimates do not take into account other factors such as physician consultation fees or time lost from work. Hence, costs shown here are likely to 
be lower than the costs actually incurred in the work-up of these patients.

\section{RESULTS}

During this 12 -month period, 537 patients were seen in the authors' clinic. Nineteen patients met the study criteria; 15 were women. The mean age was 45.5 years (range 19 to 71 years). At DUMC, the ULN values for total serum amylase and lipase are $110 \mathrm{IU} / \mathrm{L}$ and $208 \mathrm{IU} / \mathrm{L}$, respectively. Eleven of the 19 patients (58\%) had elevation of lipase alone, four of the 19 patients (21\%) had elevation of amylase alone and four of the 19 patients (21\%) had elevations of both enzymes. The ranges of maximum amylase and lipase levels were $124 \mathrm{IU} / \mathrm{L}$ to $335 \mathrm{IU} / \mathrm{L}$ and $226 \mathrm{IU} / \mathrm{L}$ to $600 \mathrm{IU} / \mathrm{L}$, respectively. All patients had normal renal function. Seventeen of the 19 patients $(89.5 \%)$ had nonspecific abdominal pain, and three of the 17 patients had associated nausea. Of the remaining two patients $(10.5 \%)$, one was completely asymptomatic, and the other had intermittent vomiting. After imaging with one or more of ultrasound, CT, MRCP, EUS and ERCP, small bowel follow through studies and hepatobiliary scans, 15 patients $(78.9 \%)$ were thought to have a normal pancreas. Three patients (15.8\%) had mild or equivocal changes of chronic pancreatitis - two of these patients had elevated lipase alone, the other elevated amylase alone. One patient $(5.3 \%)$ had a pseudocyst identified at the tail of the pancreas that did not require surgery; this patient had elevation of both amylase and lipase. The results are summarized in Tables 1 and 2. Of the 15 patients shown to have no pancreatic disease, no diagnosis was made in seven patients. One patient was thought to have nonulcer dyspepsia, one patient had significant gastroesophageal reflux disease, one patient had possible transient lymphadenitis, three patients met the Rome criteria for irritable bowel syndrome, one patient had abdominal adhesions and one patient had significant depression.

To assign an average cost per patient, the authors combined the charges made to patients for all procedures performed (charges at DUMC in 2000) and divided this amount by the number of patients. By this simplistic method, a cost of US $\$ 2,255$ per patient investigated for the cause of nonspecific abdominal symptoms and mild elevations of lipase, amylase or both enzymes was estimated.

\section{DISCUSSION}

Chronic hyperamylasemia may be due to extrapancreatic disorders because amylase is found in several organs, and overall pancreatic amylase accounts for only about $40 \%$ of total amylase (13-15); salivary isoamylase is the other main form of amylase. Raised serum amylase level is associated with diseases of the biliary tract, liver, intestines, central nervous system, genitourinary tract, lungs and salivary glands. Renal failure or liver dysfunction may result in a high amylase level due to decreased serum clearance or decreased catabolism. All of the patients in the present study had normal liver and renal function. One study of 117 patients with persistent hyperamylasemia and no obvious cause after investigation found that the pancreas was not the source in nearly $80 \%$ of the patients (8). The study concluded that such persistent puzzling hyperamylasemia is unlikely to be pancreatic in origin and that isoamylase fractionation may be a more appropriate initial test rather than extensive investigation. The authors also suggested that the persistent hyperamylasemia in their patient group was also unlikely to be pathological, and that it should be considered a normal variant, possibly due to a higher balance point in the homeostasis between production and catabolism. Our study group most likely is a different entity. Although we did not confirm that any elevation in amylase was of the pancreatic isoform, four of the eight patients with elevated amylase also had elevated lipase levels. Pancreatic acinar cells are the predominant source of lipase, and 15 of the 19 patients in our study had elevated lipase levels. Thus, the majority of our patients were likely to have pancreatic sources for their increased amylase and/or lipase.

Previous studies have suggested that persistent hyperamylasemia of pancreatic origin in the absence of symptoms, signs or imaging evidence of underlying pancreatic disease is a benign condition (6-8). Chronic elevations of amylase were studied by Gullo (7), who noted fluctuation over time, including periods of normalization - most patients in this study were followed up over several years. Gullo concluded that chronic nonpathological pancreatic hyperamylasemia is a distinct entity, but that the reasons for enzyme alteration are unknown. Our group was more heterogeneous with reference to the duration of elevated enzymes. Some patients were investigated with isolated enzyme elevation associated with symptoms whereas others had elevated enzymes over a period of several years. As in previous studies, we found that there was fluctuation of the amylase and/or lipase levels over time, with occasional periods of normalization. Gullo (16) also suggested recently that pancreatic hyperamylasemia in healthy subjects may occur with a familial distribution. In addition, there have been reports of macroamylasemia, a condition in which normal serum amylase is bound to immunoglobulin $\mathrm{A}$ and as a result is not filtered at the glomerulus $(17,18)$. It is exceedingly rare for hyperlipasemia and macroamylasemia to coexist (19), and hence macroamylasemia is an unlikely explanation for the elevated amylase levels in the patients in our study. Serum amylase levels may increase physiologically after the seventh decade (20), but most of our patients were much younger.

The phenomenon of elevated lipase in the presence of a normal amylase has also received attention. Some authorities have suggested that the measurement of amylase levels should be replaced by lipase estimation, because the latter may be more specific (21-23). One group suggests that an elevated serum lipase should not be interpreted as evidence of pancreatitis if the serum amylase is normal (9). An alternative explanation offered for increased lipase and normal amylase is that a diseased pancreas may not be able to release amylase: the healthy pancreas contains over four times more lipase than amylase $(4,9,17)$. Isolated hyperli- 
TABLE 1

Demographic, clinical, laboratory and diagnostic details of 19 patients in the present study

\begin{tabular}{|c|c|c|c|c|c|}
\hline $\begin{array}{l}\text { Patient } \\
\text { (sex) }\end{array}$ & $\begin{array}{c}\text { Age } \\
\text { (years) }\end{array}$ & $\begin{array}{c}\text { Maximum amylase (IU/L) } \\
\text { (time interval } \\
\text { of abnormalities) }\end{array}$ & $\begin{array}{c}\text { Maximum lipase (IU/L) } \\
\text { (time interval } \\
\text { of abnormalities) }\end{array}$ & $\begin{array}{l}\text { Symptoms } \\
\text { (duration) }\end{array}$ & Investigations \\
\hline $1(F)$ & 46 & Normal range & $\begin{array}{c}303 \\
(9 / 98-10 / 01)\end{array}$ & $\begin{array}{l}\text { Epigastric pain } \\
\text { (4 years) }\end{array}$ & $\begin{array}{l}\text { US/CT abdomen } \\
\text { normal }\end{array}$ \\
\hline $2(F)$ & 41 & $\begin{array}{c}146 \\
\text { (5/01-isolated } \\
\text { measurement) }\end{array}$ & $\begin{array}{c}324 \\
\text { (5/01-isolated } \\
\text { measurement) }\end{array}$ & $\begin{array}{l}\text { Nausea/vomiting/ } \\
\text { RUQ pain } \\
\text { (3 years) }\end{array}$ & $\begin{array}{c}\text { MRCP, SBFT } \\
\text { normal. Previous } \\
\text { ERCP normal but } \\
\text { complicated by } \\
\text { pancreatitis }\end{array}$ \\
\hline $3(F)$ & 19 & $\begin{array}{c}335 \\
(4 / 01-6 / 01)\end{array}$ & Normal range & $\begin{array}{l}\text { Abdominal pain } \\
\text { (3 months) }\end{array}$ & $\begin{array}{c}\text { US/CT abdomen, } \\
\text { ERCP, hepatobiliary scan } \\
\text { (all normal) }\end{array}$ \\
\hline $4(F)$ & 33 & $\begin{array}{l}\text { Normal range } \\
(5 / 01-6 / 01)\end{array}$ & $\begin{array}{c}252 \\
\text { (1 year) }\end{array}$ & Vomiting & $\begin{array}{l}\text { US abdomen, oral } \\
\text { cholecystogram, barium } \\
\text { meal (all normal) }\end{array}$ \\
\hline $5(F)$ & 52 & Normal range & $\begin{array}{c}226 \\
\text { (4/01-isolated } \\
\text { measurement) }\end{array}$ & $\begin{array}{l}\text { Mild RUQ pain } \\
\quad(2 \text { weeks })\end{array}$ & $\begin{array}{l}\text { US/CT abdomen } \\
\text { (normal) }\end{array}$ \\
\hline $6(\mathrm{M})$ & 38 & Normal range & $\begin{array}{c}460 \\
(7 / 01-10 / 01)\end{array}$ & $\begin{array}{l}\text { LUQ/epigastric pain } \\
\qquad(6 \text { months })\end{array}$ & $\begin{array}{l}\text { US/CT abdomen- } \\
\quad(\text { normal x2) }\end{array}$ \\
\hline $7(\mathrm{M})$ & 48 & $\begin{array}{c}212 \\
(4 / 01-9 / 01)\end{array}$ & Normal range & $\begin{array}{l}\text { Nausea/vomiting/ } \\
\text { mild RUQ pain } \\
\text { (several years) }\end{array}$ & $\begin{array}{l}\text { US/CT abdomen, } \\
\text { hepatobiliary scan } \\
\text { (all normal) }\end{array}$ \\
\hline $8(F)$ & 61 & Normal range & $\begin{array}{c}335 \\
(7 / 96-1 / 01)\end{array}$ & $\begin{array}{l}\text { Abdominal pain } \\
\quad(1 \text { year })\end{array}$ & $\begin{array}{l}\text { US/CT abdomen, EUS } \\
\text { pancreas: final } \\
\text { diagnosis of mild } \\
\text { chronic pancreatitis }\end{array}$ \\
\hline $9(F)$ & 64 & $\begin{array}{c}124 \\
\text { (8/01-isolated } \\
\text { measurement) }\end{array}$ & Normal range & $\begin{array}{l}\text { LUQ pain } \\
\text { (10 years) }\end{array}$ & $\begin{array}{l}\text { CT abdomen, EUS } \\
\text { pancreas, MRCP } \\
\text { (all normal) }\end{array}$ \\
\hline $10(F)$ & 61 & Normal range & $\begin{array}{c}329 \\
(9 / 01-12 / 01)\end{array}$ & $\begin{array}{l}\text { Abdominal pain } \\
\text { (4 months) }\end{array}$ & $\begin{array}{l}\text { CT abdomen, EUS } \\
\text { pancreas, ERCP, } \\
\text { hepatobiliary scan } \\
\text { (all normal) }\end{array}$ \\
\hline $11(F)$ & 36 & Normal range & $\begin{array}{c}402 \\
(4 / 01-5 / 01)\end{array}$ & $\begin{array}{l}\text { RUQ pain } \\
\text { (6 months) }\end{array}$ & $\begin{array}{l}\text { CT abdomen, hepatobiliary } \\
\text { scan (normal). EUS } \\
\text { pancreas: low suspicion } \\
\text { for mild changes of } \\
\text { chronic pancreatitis }\end{array}$ \\
\hline $12(F)$ & 48 & Normal range & $\begin{array}{c}558 \\
(5 / 00-6 / 01)\end{array}$ & $\begin{array}{c}\text { LUQ pain } \\
\text { (several years) } \\
\text { (Hepatitis C positive) }\end{array}$ & $\begin{array}{l}\text { EUS pancreas x2, } \\
\text { MRCP, US abdomen } \\
\text { (normal pancreas) }\end{array}$ \\
\hline
\end{tabular}

CT Computed tomography; ERCP Endoscopic retrograde cholangiopancreatography; EUS Endoscopic ultrasound; IU International units; LUQ Left upper quadrant; MRCP Magnetic resonance cholangiopancreatography; RUQ Right upper quadrant; SBFT Small bowel follow through; US Ultrasound 
TABLE 1 (continued)

Demographic, clinical, laboratory and diagnostic details of 19 patients in the present study

\begin{tabular}{|c|c|c|c|c|c|}
\hline $\begin{array}{l}\text { Patient } \\
\text { (sex) }\end{array}$ & $\begin{array}{c}\text { Age } \\
\text { (years) }\end{array}$ & $\begin{array}{c}\text { Maximum amylase (IU/L) } \\
\text { (time interval } \\
\text { of abnormalities) }\end{array}$ & $\begin{array}{c}\text { Maximum lipase (IU/L) } \\
\text { (time interval } \\
\text { of abnormalities) }\end{array}$ & $\begin{array}{l}\text { Symptoms } \\
\text { (duration) }\end{array}$ & Investigations \\
\hline $13(F)$ & 51 & Normal range & $\begin{array}{c}236 \\
(4 / 01 \text {-isolated } \\
\text { measurement })\end{array}$ & $\begin{array}{l}\text { Abdominal pain, } \\
\text { occasional nausea } \\
\text { (9 months) }\end{array}$ & $\begin{array}{l}\text { EUS pancreas } \\
\text { (normal) }\end{array}$ \\
\hline $14(\mathrm{M})$ & 32 & $\begin{array}{c}143 \\
(7 / 00-12 / 00)\end{array}$ & Normal range & $\begin{array}{l}\text { Abdominal pain } \\
\text { (1 year) }\end{array}$ & $\begin{array}{c}\text { Hepatobiliary scan } \\
\text { (normal) } \\
\text { EUS pancreas } \\
\text { (mild chronic pancreatitis) }\end{array}$ \\
\hline $15(F)$ & 71 & $\begin{array}{c}146 \\
(1 / 97-10 / 00)\end{array}$ & $\begin{array}{c}337 \\
(1 / 97-10 / 00)\end{array}$ & Asymptomatic & $\begin{array}{l}\text { US/CT abdomen } \\
\text { (normal) }\end{array}$ \\
\hline $16(F)$ & 50 & $\begin{array}{c}140 \\
\text { (2/01-isolated } \\
\text { measurement) }\end{array}$ & $\begin{array}{c}305 \\
\text { (2/01-isolated } \\
\text { measurement) }\end{array}$ & $\begin{array}{l}\text { Abdominal pain } \\
\quad \text { (years) }\end{array}$ & $\begin{array}{c}\text { US abdomen } \\
\text { (normal) CT abdomen/ } \\
\text { ERCP (pancreatic } \\
\text { tail pseudocyst) }\end{array}$ \\
\hline $17(\mathrm{~F})$ & 50 & $\begin{array}{c}235 \\
(3 / 98-2 / 01)\end{array}$ & $\begin{array}{c}258 \\
(3 / 98-2 / 01)\end{array}$ & $\begin{array}{c}\text { Right-sided } \\
\text { abdominal pain } \\
\text { (several years) }\end{array}$ & $\begin{array}{c}\text { ERCP, EUS pancreas, } \\
\text { CT abdomen } \\
\text { (all normal) }\end{array}$ \\
\hline $18(\mathrm{M})$ & 26 & Normal range & $\begin{array}{c}600 \\
(6 / 00-1 / 01)\end{array}$ & $\begin{array}{l}\text { Epigastric pain } \\
\text { (6 months) }\end{array}$ & $\begin{array}{l}\text { US/CT abdomen } \\
\text { (normal) }\end{array}$ \\
\hline $19(\mathrm{~F})$ & 43 & Normal range & $\begin{array}{c}498 \\
\text { (3/01-isolated } \\
\text { measurement) }\end{array}$ & $\begin{array}{c}\text { RUQ pain } \\
\text { (several months) }\end{array}$ & $\begin{array}{l}\text { CT abdomen } \\
\text { (normal) } \\
\text { Hepatobiliary scan } \\
\text { (suboptimal study) }\end{array}$ \\
\hline
\end{tabular}

CT Computed tomography; ERCP Endoscopic retrograde cholangiopancreatography; EUS Endoscopic ultrasound; IU International units; LUQ Left upper quadrant; MRCP Magnetic resonance cholangiopancreatography; RUQ Right upper quadrant; SBFT Small bowel follow through; US Ultrasound

TABLE 2

Summary of investigations performed in the work-up of patients in the present study

\begin{tabular}{cccccccc}
\hline & CT abdomen & US & ERCP & MRCP & EUS & Hepatobiliary scan & Other \\
\hline Normal & 13 & 11 & 4 & 3 & 6 & 6 & 3 \\
& & & & & & $\begin{array}{c}\text { (one suboptimal } \\
\text { study) }\end{array}$ & $\begin{array}{c}\text { (SBFT, BM, OC } \\
\text { once each) }\end{array}$
\end{tabular}

Abnormal

1

3

BM Barium meal; CT Computed tomography; ERCP Endoscopic retrograde cholangiopancreatography; EUS Endoscopic ultrasound; MRCP Magnetic resonance cholangiopancreatography; OC Oral cholecystography; SBFT Small bowel follow through; US Ultrasound

pasemia has been reported in $11 \%$ to $84 \%$ of patients with nonpancreatic abdominal pain (24-26). Tetrault et al (26) described a series of 493 patients with abdominal pain and isolated lipase elevations in which they found more nonpancreatic than pancreatic disease. Macrolipasemia is much less common than macroamylasemia and is unlikely to be the cause of increased lipase levels in any of our patients $(9,17)$.

This was a retrospective analysis, and obviously there remains the possibility of case selection bias. As a tertiary referral centre, we preferentially evaluate patients with persistent and puzzling hyperamylasemia. There was no fixed algorithm for investigation of these patients, but all of the patients identified during the study period of having raised amylase and/or lipase levels underwent at least two radiological or endoscopic diagnostic procedures. Many patients had an abdominal CT as part of their work-up. Although this is not the gold standard for diagnosis of pancreatic disease, a normal CT result in the setting of minimal symptoms and low level pancreatic enzyme elevations should make one consider whether further investigation is actually justified. However, we acknowledge that CT alone may miss pancreatic disease, but note that most of our patient 
group had ultrasound, MRCP or ERCP, in addition. We plan to perform a prospective study of such patients in the future.

In our experience, the majority $(78.9 \%)$ of patients with nonspecific abdominal pain and mild elevations of amylase and/or lipase had no identifiable pancreatic pathology. Almost all of these patients had more than one radiological or endoscopic investigation during the course of their workup. Indeed, several patients had multiple, often repeated, imaging investigations. The diagnostic yield in patients with elevations of lipase less than three times the ULN but normal amylase was particularly poor. However, because only four of the total of 19 patients had suspected or actual pathology, it is not possible to predict whether elevation of both pancreatic enzymes is more predictive of disease than elevation of either enzyme alone. Our crude estimate of the average cost of investigating these patients is substantial (average charges of US\$2,255) and is likely to be a significant underestimate of the true cost, because other costs such as those for professional fees, repeat laboratory investigations and clinic time are not taken into account. We acknowledge that it is impossible to make firm conclusions as to the cost effectiveness of the investication of these patients based on the above simple cost calculations that are particular to our institution, but our figures show that extensive investigation of these patients is very costly, and is probably unnecessary in the majority of cases.

\section{REFERENCES}

1. Mergener K, Baillie J. Acute pancreatitis. BMJ 1998;316:44-8.

2. Gorelick FS. Acute pancreatitis. In: Yamada T, ed. Textbook of Gastroenterology, 2nd edn. Philadelphia: Lippincott, 1995:2064-91.

3. Agarwal N, Pitchumoni CS, Sivaprasad AV. Evaluating tests for acute pancreatitis. Am J Gastroenterol 1990;85:356-66.

4. Clavien PA, Burgan S, Moossa AR. Serum enzymes and other laboratory tests in acute pancreatitis. Br J Surg 1989;76:1234-43.

5. Quilez C, Martinez J, Gomez A, et al. Chronic elevation of enzymes of pancreatic origin in asymptomatic patients. Gastroenterol Hepatol 1998;21:209-11.

6. Martinez J, Gomez A, Palazon JM, Gutierrez A, Perez-Mateo M. Asymptomatic chronic hyperamylasemia of unknown origin: An infrequent entity? Gastroenterology 1997;112:1057.

7. Gullo L. Chronic nonpathological hyperamylasemia of pancreatic origin. Gastroenterology 1996;110:1905-8.

8. Warshaw AL, Hawboldt MM. Puzzling persistent hyperamylasemia, probably neither pancreatic nor pathologic. Am J Surg 1988;155:453-6.

9. Frank B, Gottlieb K. Amylase normal, lipase elevated: Is it pancreatitis? A case series and review of the literature. Am J Gastroenterol 1999;94:463-9.

10. Lankisch PG, Burchard-Reckert S, Lehnick D. Underestimation of acute pancreatitis: Patients with only a small increase in amylase/lipase levels can also have or develop severe acute pancreatitis. Gut 1999;44:542-4.

11. Clave P, Guillaumes S, Blanco I, et al. Amylase, lipase, pancreatic isoamylase, and phospholipase $\mathrm{A}$ in diagnosis of acute pancreatitis. Clin Chem 1995;41:1129-34.

12. Lankisch PG, Petersen M, Gottesleben F. High, not low, amylase and lipase levels indicate severe acute pancreatitis! Z Gastroenterol 1994;32:213-5.

13. Heffernon JJ, Fridhandler L, Berk JE, Shimamura J. Assay of amylase and isoamylase activities in serum and urine. Modifications in methods and range of normal values. Am J Gastroenterol 1977;67:473-7.

\section{CONCLUSIONS}

In our experience, extensive investigation of patients with nonspecific abdominal symptoms and mild elevations of amylase, lipase or both enzymes is both costly and gives a poor yield. No case of malignancy was identified in the extensive investigation of the patients in this study group. Our findings are in keeping with previous studies suggesting that very few cases of chronic, unexplained hyperamylasemia have a pancreatic origin. We agree, and this can probably be extended to patients with mild (less than three times the ULN) lipase elevations. In agreement with previous studies of similar groups of patients, we suggest that persistent hyperamylasemia is rarely predictive of pathology, and is likely a benign condition. How such patients should be evaluated is still not entirely clear. It is possible that prescreening (ie, before imaging) with isoamylase determination could reduce the number of patients undergoing expensive imaging procedures, and this may be the best initial strategy. If this shows the raised amylase or lipase to be of pancreatic origin, we suggest that many of these patients do not require further investigation. Certainly, if CT reveals no pancreatic pathology, one should question the need for further investigation. The cost effectiveness and risk-benefit ratio of extensive investigation of this group of patients warrants further study.

14. Whitten RO, Chandler WL, Thomas MG, Clayson KJ, Fine JS. Survey of alpha-amylase activity and isoamylases in autopsy tissue. Clin Chem 1988;34:1552-5.

15. Panteghini M, Pagani F. Diagnostic value of measuring pancreatic lipase and the $\mathrm{P} 3$ isoform of the pancreatic amylase isoenzyme in serum of hospitalized hyperamylasemic patients. Clin Chem 1989;35:417-21.

16. Gullo L. Familial pancreatic hyperenzymemia. Pancreas 2000;20:158-60.

17. Levitt MD, Duane WC, Cooperband SR. Study of macroamylase complexes. J Lab Clin Med 1972;80:414-22.

18. Berk JE, Kizu H, Wilding P, Searcy RL. Macroamylasemia: A newly recognized cause for elevated serum amylase activity. $\mathrm{N}$ Engl J Med 1967;277:941-6.

19. Gullo L, Pezzilli R, Tomassetti P. Unusual association of macroamylasemia and hyperlipasemia: Report of two cases. Am J Gastroenterol 1996;91:2441-2.

20. Ueda M, Araki T, Shiota T, Taketa K. Age and sex-dependent alterations of serum amylase and isoamylase levels in normal human adults. J Gastroenterol 1994;29:189-91.

21. Orebaugh SL. Normal amylase levels in the presentation of acute pancreatitis. Am J Emerg Med 1994;12:21-4.

22. Tietz NW, Shuey DF. Lipase in serum - the elusive enzyme: An overview. Clin Chem 1993;39:746-56.

23. Corsetti JP, Cox C, Schulz TJ, Arvan DA. Combined serum amylase and lipase determinations for diagnosis of suspected acute pancreatitis. Clin Chem 1993;39:2495-9.

24. Chase CW, Barker DE, Russell WL, Burns RP. Serum amylase and lipase in the evaluation of acute abdominal pain. Am Surg 1996;62:1028-33.

25. Gumaste VV, Roditis N, Mehta D, Dave PB. Serum lipase levels in nonpancreatic abdominal pain versus acute pancreatitis. Am J Gastroenterol 1993;88:2051-5.

26. Tetrault GA. Lipase activity in serum measured with Ektachem is often increased in nonpancreatic disorders. Clin Chem $1991 ; 37: 447-51$. 


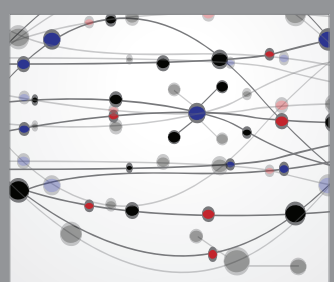

The Scientific World Journal
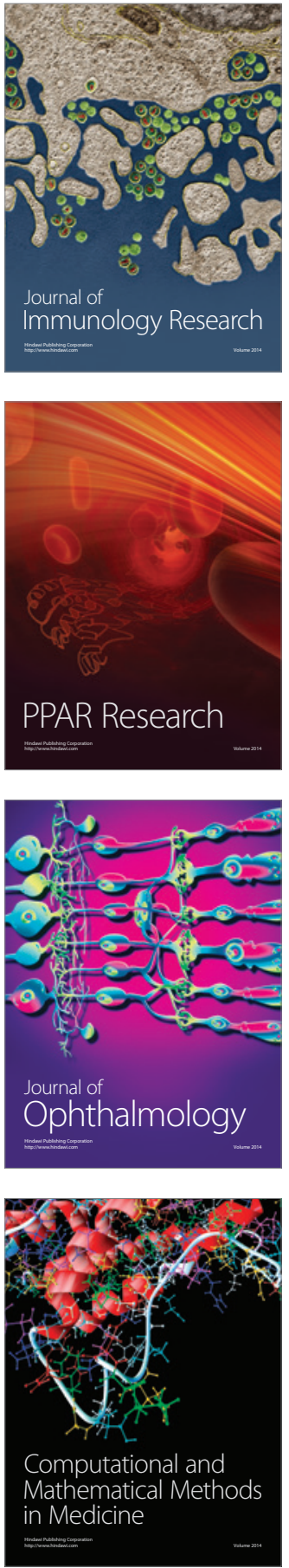

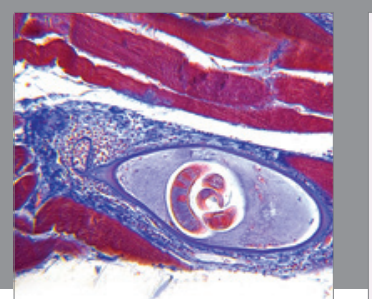

Gastroenterology Research and Practice

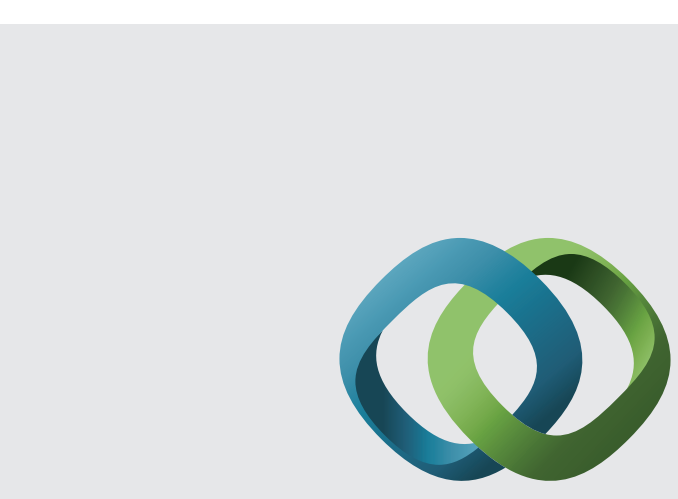

\section{Hindawi}

Submit your manuscripts at

http://www.hindawi.com
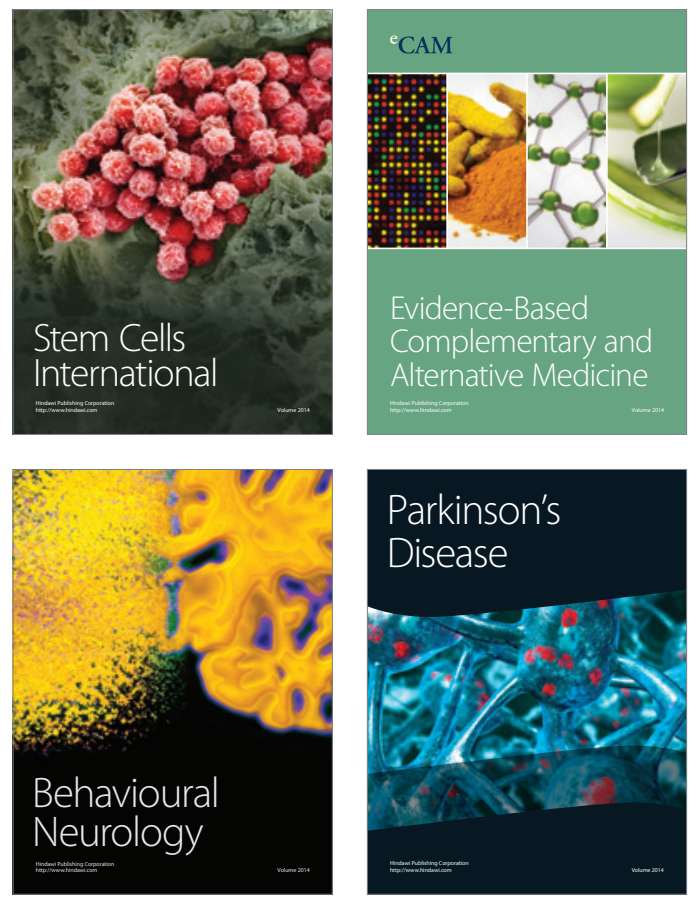
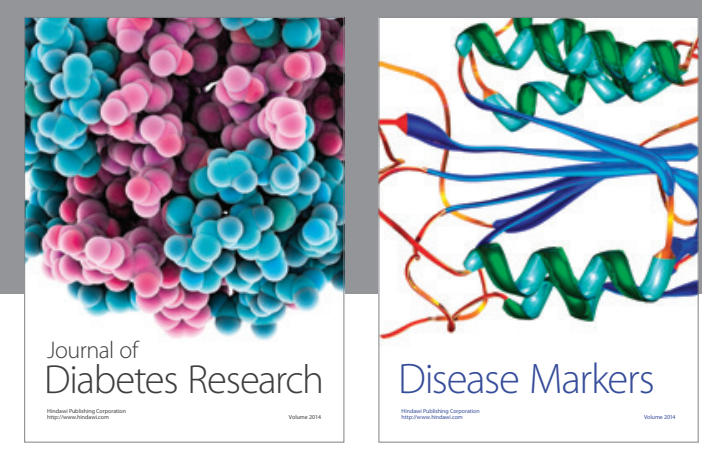

Disease Markers
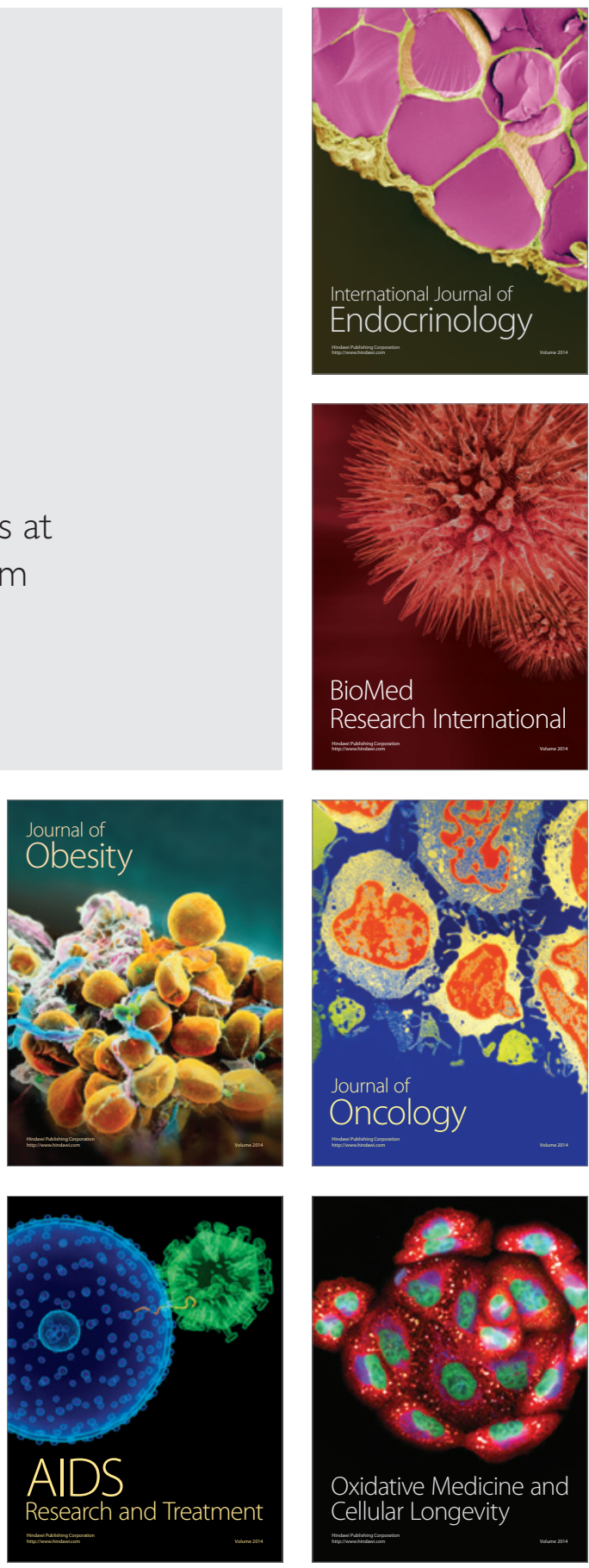